\title{
KAMPUNG MASPATI AS A SUSTAINABLE KAMPUNG IN SURABAYA CITY
}

\author{
Emiria Letfiani and Arlita Widyasari*) \\ *) Master student at Department of Architecture, Institut Teknologi Sepuluh \\ Nopember, Surabaya \\ Email : emiria20@gmail.com
}

\begin{abstract}
This paper discusses the role of kampung in sustainable urban development. Because two third of the city's population live in kampung, and most of the population are people with low and middle incomes. The kampung should be able to contribute in the development of the city. Kampung Maspati RT (Neighborhood Board) $03 R W$ (Citizen Board) 08 as the object of this research is the winner of 'Best of the Best kampung' in Green and Clean 2015 competition for developing category. This kampung was once a slum kampung, but over time, local community start to increase the quality of the kampung. The aim of this study is to demonstrate empirically that the kampung Maspati is able to improve the quality of environment, social and economic aspects. The method used in this study is descriptive qualitative. The method of data collection are observation and interviews which were done directly to the residents and also to the local environment guide. Document action also used such as photography. Results of this study shows that kampung Maspati deserves the title Best of the Best Surabaya of Green and Clean 2015 for developing category, because it has managed to improve the quality of the environment, although it is still not holistically. However, it is indirectly give some impacts in improving the economy and social welfare. Overall, the communities of kampung Maspati have made it out of the slum and contributes to the development of sustainable cities.
\end{abstract}

Keywords: kampung, sustainable urban development, Surabaya

\section{INTRODUCTION}

Sustainable urban development is being a trending topic nowadays which is among cities, towns and villages should be integrated and supported each other. It will be discussed in Habitat III along with climate change and global development (Habitat III, 2015). In this case, kampung that located in the city, also has a big role in creating a sustainable urban development.

According to Sihombing (2004) kampung is known as an unstructured, unorganized and informal settlement in relation to the broader socio-economic 
system. It can also be realised as a settlement in an urban area without infrastructure, planning or urban economic networking. Poverty and poor of quality of life are features of kampung. But today, the community in many kampungs in Indonesia are having big efforts to increase the quality of their lives and also their environment, especially in Surabaya. The Surabaya Local Government has already took an effort to improve the environment and economic quality of the community through Surabaya Green and Clean in order to create the sustainable urban development.

This paper will discuss the role of the kampung in sustainable urban development and will prove that not all the urban kampungs have poor environment quality. Kampung is housed about two third of the urban population, offering different standards of housing at different price levels, mostly for low and middle income families (Setijanti, 2006). The kampungs in the city should be able to contribute in meeting the sustainable urban development of the city. So that the city can be in stable condition. Through the participation of the kampung in sustainable urban development had an impact in reducing environmental losses which also affect the economy, socio-cultural, and the welfare of the communities.

Kampung Maspati RT 03 RW 08 was one of a slum kampung in Surabaya. Through the awareness of local community about the importance of protecting the environment, local community are slowly trying to improve the quality of the quality of the environment with all the economic limitations. From the formulation of these problems arise some research questions, namely:

1. How does the communities of kampung Maspati improving the quality of the environment in the context of sustainable urban development with very limited economic conditions?

2. What has been achieved by local communities in improving the quality of the environment which gives a considerable impact in the city of Surabaya sustainable development?

The aim of this study is to demonstrate empirically that the kampung Maspati which was once a slum area can improve the quality of the environment and give a big contribution to the sustainable urban development in general.

\section{THEORY / RESEARCH METHODS}

\section{Draft of Habitat III}

Habitat III states that sustainable development depends on how community could organize and direct the global urbanization. Therefore, UN Habitat has 17 goals to reach a global sustainability by improving the quality of the environment and man (ICSU \& ISSC, 2015). Among 17 goals of Habitat III, there are some points that relevant to this research, those are end poverty in all it forms everywhere; end hunger, achieve food security, improve nutrition and promote sustainable agriculture; ensure healthy lives and promote well-being for all at all ages; and ensure avability and sustainable management of water and sanitation for all. 


\section{Green Economy}

UNEP defines green economy as one of the results in improving human well-being and social equity, to reduce the loss of environmental and ecological scarcity (UNEP, 2011). To realize the green economy in an effort to improve the quality of the environment, there are three important aspects, which are:

1. Investment in Natural Capital

a. Agriculture: to increase green investment and guiding how to conduct economic transformation in agriculture, with the aim is to improve food security, reduce poverty, improve nutrition and health, creating jobs in remote areas, and reduce environmental pressures including reducing GHG emissions.

b. Fisheries: The purpose of the green economy in the field of fisheries is to show the current economic and social value of marine fisheries for the world and more importantly is the estimate on the overall potential of the economic sector and the social value if it is set within the framework of green economy.

c. Water: the purpose of the green economy in the aspect related to water is to meet the needs, affordability and availability of water and also to reduce the cost of water treatment for the ecosystem.

d. Forests: Forests for the support of more than 50 percent of the species on earth, which plays a vital role to protect the watershed and climate regulation (ecosystems) and there is a great cultural and symbolic significance.

2. Investments in energy efficiency and resource

a. Renewal energy: greening the energy sector will require an increase in energy efficiency and the availability of energy services a very large resource of renewal, both of which will be directed towards the reduction of greenhouse gas emissions and other pollution types. An example is the increase in energy efficiency benefits in the economic field.

b. Manufacturing: green manufacturing is very important to separate the environmental pressures from economic growth. Green manufacturing is different from conventional manufacturing which aims to reduce the amount of natural resources needed to produce finished goods through energy and materials more efficiently. The manufacturing process also reduces the negative externalities associated with the disposal and pollution. Including transport and efficient logistics which takes into account that a significant percentage of the total environmental impact due to product manufacturing.

c. Waste: green economy in the waste aspect aims to provide policy makers with guidelines on how to mobilize investments. UNEP demonstrate how green investment in the waste sector can create jobs and contribute to economic growth.

d. Buildings: Green Economy in the building sector is that the government and the private sector to use the environment and economic opportunities, such as the use of energy efficiency, water resources, to improve the health, productivity and create jobs and reduce poverty. 
e. Transportation: the presence of a green transport policy will reduce accidents and poverty moved at improving access to markets and the importance of the facility.

f. Tourism: The tourism potential of green has the potential to create jobs, supporting the local economy, reduce poverty, and improve biodiversity.

g. Major cities: with the concept of green cities can enhance social justice and quality of life, and improve public transport system.

3. Supporting the transition to a green economy world

a. Model of global green investment scenario: by applying green economy can enhance natural capital, generating gross domestic product (GDP) is higher, increasing the poor economy and creates jobs.

b. Conditions that enable: Enable a green economy means creating a context in which economic activity improve the welfare of human and social justice, and significantly reducing environmental risks and ecological scarcity .

c. Finance:. Financial investment, banking and insurance are the main channel of private financing for a green economy. Financial services and investment control trillions of dollars that could potentially be directed towards green economy.

\section{Healthy Building}

Healthy building is one of the adversely affects either the health of its occupants or the larger environment (Levin, 1995). Bad construction or neglected maintenance is the primary cause of structural hazards in homes. Bad construction leads to building defects that increase the likelihood of structural hazards and fires, which in turn increase the risk of falls, burns, and other injuries. These defects also lead to inadequate ventilation and moisture accumulation; both factors raise the levels of asthma triggers in the home (Cummins, 2001) .

Recent research has shown that certain factors present in the architectural environment affect the human immune system (Mirkine, 1996). Healthy buildings are buildings that are non-toxic construction systems, ranging from construction and finishing materials, as this affects the health of people living in the building through the indoor air in inhaled by humans . To create a healthy building then performed (Paul Bierman-Lytle \&IAI, 1992):

1. The design approach. All architectural styles (Modern, Post Modern, Classical, Rustic, Underground, Apartment, Town house, mobile home) that should result in a healthy building.

2. Building Systems. Building systems include many things, namely: heating, air conditioning, ventilation, air cleaning, plumbing, water treatment, electrical, electromagnetic shielding, system and security, entertainment / media / intercom, system maintenance, monitoring by computer to the operation and use of buildings, It is important in creating healthy buildings of the design approach which will result in a new building or a new ornament in the house, because the development is increasingly sophisticated technology which resulting in a change of equipment that use in the past and now. 
3. Building Products. Building products consist of prevention radon and mitigation systems, humidity and foundations, engineering drainage, pesticide alternatives, alternative plywood, exterior paints and wood stains, caulks, adhesives, glues, doors and windows, insulation, vapor barrier, a system of walls, floors , carpets, wallpaper, kitchen cabinets and appliances, furniture, interior paint, alternative wall, illumination. Low building materials should be free of toxic or hazard, level of acceptable risk and in environmental studies cradle-to-grave and considering the issue rainforest, energy, environmental site planning, waste disposal, recycling and policy making.

4. Maintenance / Maintenance. Treatment using communication and monitoring systems for building performance. Home management system to manage: light, music, security, telephone, air, pollutant monitors, providing maintenance schedules and records, does not pollute the building by spraying pesticides around, do not use toxic cleaners and aerosols.

\section{Sustainable Housing for Sustainable City}

Sustainable housing is to improve human welfare. In the housing, there are three dimensions of sustainability (UN-Habitat, 2012), namely:

1. Environmental Sustainability: dealing with the impact of housing on the environment and climate change, as well as the environmental impact of the housing itself.

2. Social and cultural Sustainability: associated circuitry fundamental social needs such as housing affordability, decent housing and healthy, achieving the needs of transport and community facilities.

3. Economic Sustainability: related to capital assets made by man's most valuable and durable.

\section{The Criteria of Surabaya Green and Clean for Developing Category}

Surabaya Green and Clean is one of the collaboration programme between the local government, private, NGO, and mass media such as Jawa Pos and Radar Surabaya. This programme started from the citizen concerns in the environment issues. It emerges to form a strategy to educate the inhabitants to improve their environment. Surabaya Green and Clean also used as a competition event of cleaning, greening and healthy environment among districts in Surabaya city. So it can emerge the inhabitants' interest to keep their environment clean, green and healthy.

According to the head of Surabaya Green and Clean Programme from Jawa Pos Newspaper, besides of the communities creativity in effort to improve their environmet, the other criteria in assessing the competition are :

1. An effort to reduce the quantity of the trash up to $80 \%$;

2. The communities contribution for their environment;

3. The ability of the RT and RW to educate the others RT and RW from another area to apply this programme to their environment;

4. Application of infiltration wells such as biopor in their environment;

5. Utilization the remaining area in their environment to plant a various plants such as urban farming, flowers, and other benificial plants. 
By this program, the government hope that it gives an impact for the city's sustainability. Surabaya Green and Clean is a community based programme which the community in the kampungs is being the key of development to create an environment development community based in Surabaya city (Kumalasari, 2015).

\section{Research Method}

The research method that used in this paper is descriptive qualitative. While the technique of data collection were by interview to the citizens and the kampung environment guide. It was also conducted through observation and photographic documentation.

\section{RESULTS AND DISCUSSION}

\section{Overview Location Study}

Kampung Maspati is located in RT 03 RW 08 Kampung Bubutan, Surabaya (see Figure 1).

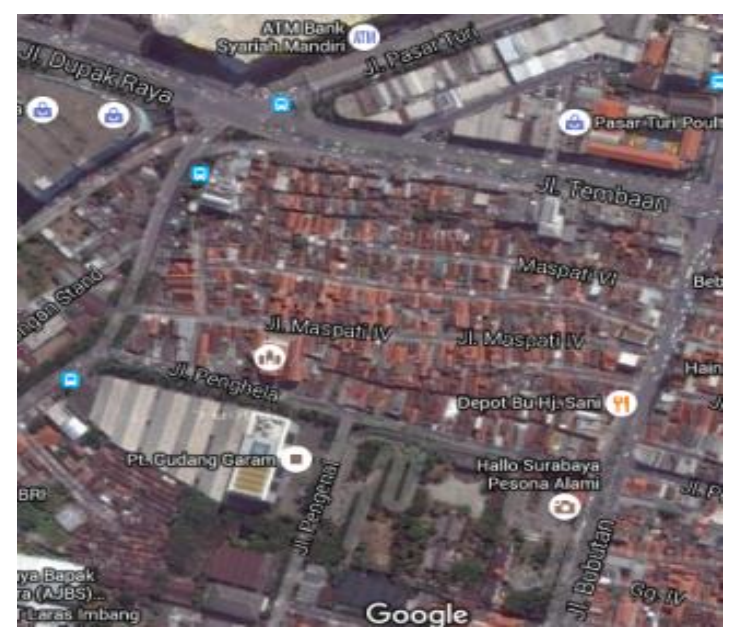

Figure 1. Location of Study

Source : Google Maps, 2015

In terms of social demography in RT 03 RW 08, community of Kampung Maspati have 60 families, most are work as employees around the kampung. There is also low businessman which employed the local communities. Economically, the communities are middle and lower families. The physical condition of the kampung looks green and clean. There are various plants that can be found all along the kampung's corridor such as toga plants, ornamental plants, and vegetables. Plants planted in polybags, hydroponic systems, and urban farming. Along the corridors are 
decorated by interesting and creative paintings to persuade the communities to always care for their environment.

\section{The Community of Kampung Maspati Ways to Achieve Best of the Best Category}

In 2015, Kampung Maspati was achieved best of the best category in Surabaya Green and Clean. Formerely, Kampung Maspati was a slum area. However, there was an old lady, named Mrs. M who clean all along the pathways in RT 03 by herself. She took this action based on her initiation without forced by anyone in order to stimulate the local community awareness in improving the environment quality. Because of her action, many of local communities touched by her and follow her. Local communities give their contribution based on their skill.

The community in Kampung Maspati do not rely on government assistance, so they do a concept called jimpitan (local community contribution) to collect money from the residents in RT 03 which amount of 500 rupiahs per day. The collected money then used to buy some plants and take care of the environment of the kampung.

\section{Kampung Maspati's Achievements}

Kampung Maspati could be the winner of best of the best category because they had applied some requirements, such as :

\section{WWTP (Waste Water Treatment Plant)}

Kampung Maspati could achieve the goal 6 of SGD's which is to ensure the availability and sustainability of water management because the local people in Kampung Maspati capable to create a waste water treatment plant. The WWTP which built there used to filtrate residents waste water to become cleaner. However, the filtrated water could not use as clean water, it is used for watering the plants.

Furthermore, people can save money for monthly payment of water because usually the local people use clean water for watering the plants or washing tehir vehicles. However, since the WWTP had built, the local people can use filtrated water for those activities. The WWTP is also contributed to reduce environment degradation.

\section{Composter}

a. Environmental sustainability: the composter in kampung maspati RT $03 \mathrm{RW}$ 08 helped the city in general to reduce the quantity of waste. It is can be use as fertilizer.

b. Healthy building: communities utilize and process the waste into compost. But for plastic waste collected and sold. 


\section{Urban Farming and Greening}

a. SDG's: the community in Kampung Maspati reachs Goal-2, Goal-12, Goal-13 of SDG's because the community has applied urban farming for selfconsume.

b. Green economy: the implementation of urban farming in the kampung Maspati RT 03 RW 08 contributes to food security because kampung can provide vegetables for self-consumption and also save the cost of a monthly expenditure of up to $\pm 50,000$ rupiahs / month.

c. Environmental sustainability: urban farming in the kampung Maspati is not using pesticides so it is not damage the micro environment.

\section{Garbage and Waste Bank Management}

a. Green economy: the application of the waste bank is very profitable for the kampung because the community can have savings through non-organic trash such as plastic bottles and the like.

b. Environmental sustainability: non-organic waste cannot be merged by the soil so that the presence of the waste bank can reduce environmental scarcity by collecting and selling the plastic trash (Figure. 2)

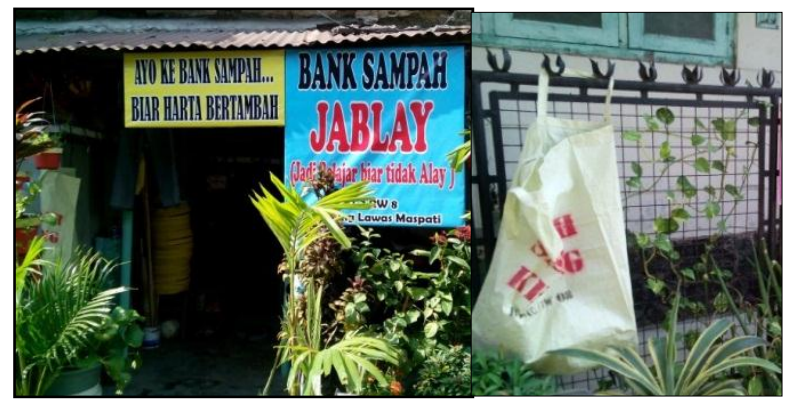

Figure 2. Waste Bank Management Soure : Observation, 2015

\section{Clothes Recycling}

a. Green economy: the recycled clothes in addition using old cloth, the community is also used plastic waste which processed as ornate costumes. For now clothes recycling is only made for the kampung mascot and is expected to contribute to the future economy of the kampung.

b. Environmental sustainability: the creativity of clothes recycling of plastic waste can reduce waste bins which created positive impact on environmental sustainability (Figure 3.). 


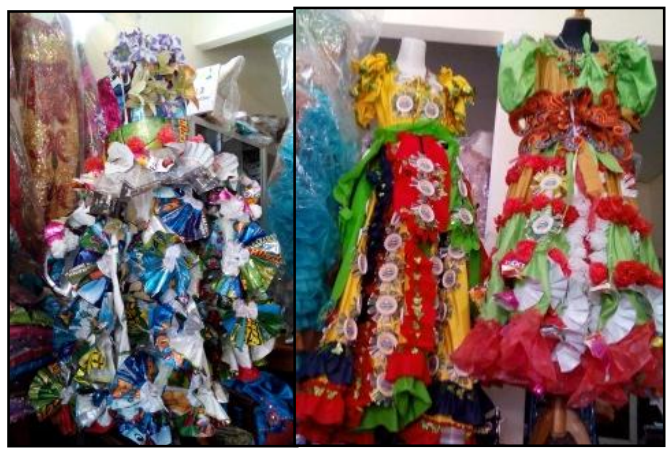

Figure 3. Clothes Recycling Soure : Observation, 2015

\section{CONCLUSION}

In general, aspects of the habitat III draft, SDG's goals, healthy building and sustainable housing for sustainable cities, Kampung Maspati is already supporting more than $70 \%$ of that goal. Thus kampung Maspati RT 03 RW 08 is feasible to obtain the title of "best of the best" kampung in Surabaya Green and Clean event of 2015. It shows through their effort to reduce the solid waste quantity, application of urban farming, reuse the water waste from household and other achievement that the local communities have done. So it means that the Surabaya Green and Clean Programme could raise the communities role to keep their environment clean, green and healthy.

In addition, the Kampung Maspati contributes to create sustainable city by increasing its quality of environment. It is also give positive impacts on improving local community economy and social. So, it is important to raise local community participation in development to realized sustainable city.

\section{REFERENCES}

Brochure Habitat III (accessed from unhabitat.org on August, 30 2015).

Cummins, S. K. \& Jackson, R. J. (2001), The Built Environment and Children's Health, Elsevier Inc.

ICSU\&ISSC. (2015), Review of Target for the Sustainable Development Goals : The Science Perspective, Paris.

Kumalasari. (2015), Evaluasi Program Surabaya Green and Clean Berbasis Sustainable Development ( Studi pada Dinas Kebersihan dan Pertamanan Kota Surabaya), Jurusan Administrasi Publik, Fakultas Ilmu Administrasi, Universitas Brawijaya. Jurnal Administrasi Publik (JAP), Vol.3, No.10, 17531757.

Levin, H. (1995), Building Ecology : An Architect's Perspective on Healthy Buildings. Prepared for presentation as a keynote lecture at 'healthy building 1995', Milan, Italy, September 10 -15. 
Mirkine, A. (1996), Healing Environment: Physical, Spiritual, Emotional and Psychological Factors in Architecture that Promote Health. Architecture, University of New Mexico.

Paul Bierman-Lytle \& AIA. (1992), Healthy Building : Low Toxic Construction System, Products and Approaches on Sustainable Cities. Bob Walter et al (editor). Eco-Home media : LA, California, USA.

Setijanti, P. (2006) Low-Income Inner-City Settlement Processes : a Surabaya Study. PhD Thesis, Faculty of Architecture, Building and Planning, The University of Melbourne.

Sihombing, A. (2004), The Transformation of Kampung Kota : Symbiosys Between Kampung and Kota, a Case Study from Jakarta, Departement of Architecture, University of Indonesia.

UNEP. (2011), Towards A Green Economy : Pathways to Sustainability Development and Poverty Eradication. ( accessed from www.unep.org/greeneconomy on November, 2015).

UN-HABITAT. (2012) Sustainable Housing for Sustainable Cities : A Policy Framework for Developing Countries. United Nations Human Settlements Programme : first published in Nairobi, Kenya. 